\title{
Suppression of Portal Venous Insulin Concentration by Epinephrine in the Conscious Monkey*
}

\author{
R. E. Mither and J.S. SoELDNER
}

Department of Physiology, Harvard School of Public Health; The Elliott P. Joslin Research Laboratory, Department of Medicine; Peter Bent Brigham Hospital; Harvard Medical School; and the Diabetes Foundation, Inc.

Received: September 11, 1968

Summary. Conscious male rhesus monkeys were given epinephrine bitartrate ( $1 \mu \mathrm{g} / \mathrm{kg} . \mathrm{min})$ through a catheter implanted in the right internal jugular vein. Blood samples were taken from the portal vein through another catheter before, during, and after a 15-minute-long jugular infusion. Sugar in the plasma rose during, and was still high $10 \mathrm{~min}$ after the infusion, while mean immunoreactive insulin decreased during the infusion and rose dramatically after its termination. Ergotamine tartrate (14 $\mu \mathrm{g} / \mathrm{kg} . \mathrm{min})$ while not preventing a rise in plasma sugar concentration, inhibited the expected insulin decrease during epinephrine infusion.

Diminution de la concentration d'insuline dans la veine porte, provoquée par l'adrénaline chez le singe éveillé

Résumé. Du bitartrate d'adrénaline $(1 \mu \mathrm{g} / \mathrm{kg} . \mathrm{min})$ a été administré à des singes rhésus mâles éveillés, par un cathéter implanté dans la veine jugulaire interne droite. Des échantillons de sang étaient prélevés de la veine porte par un autre cathéter, avant, pendant et après une infusion jugulaire de $15 \mathrm{~min}$. Le sucre du plasma augmentait pendant l'infusion et était encore élevé 10 min après celle-ci, alors que la concentration moyenne d'insuline immunoréactive diminuait pendant l'infusion et aug- mentait fortement quand elle était terminée. Alors que le tartrate d'ergotamine (14 $\mu \mathrm{g} / \mathrm{kg}$.min) n'empêchait pas l'augmentation de la concentration du sucre du plasma, il inhibait la diminution attendue de l'insuline, pendant l'infusion d'adrénaline.

Senkung der Insulinspiegel im Portalvenenblut von Rhesus-Affen im Wachzustand durch Adrenalin

Zusammenfassung. Männliche Rhesus-Affen erhielten $1 \mu \mathrm{g} / \mathrm{kg} \cdot \mathrm{min}$ Adrenalintartrat durch einen Katheter in die rechte vena jugularis interna. Aus einem Portalvenenkatheter wurden vor, während und nach der 15-minütigen Infusion in die Jugularvene Blutproben entnommen. Die Blutzuckerspiegel stiegen unter der Infusion an und waren 10 min danach noch erhöht, während das immunoreaktive Insulin unter der Infusion abfiel, um erst nach ihrer Beendigung stark anzusteigen. 14 $\mu \mathrm{g} / \mathrm{kg} . \mathrm{min}$ Ergotamintartrat verhinderten zwar den Blutzuckeranstieg nicht, führten aber zu einer Hemmung des Insulinabfalls während der Adrenalin-Infusion.

Key-words. Epinephrine, ergotamine, rhesus monkey, portal vein insulin, portal vein blood glucose.

\section{Introduction}

Investigators have shown that epinephrine prevents a glucose-stimulated rise in immunoreactive insulin (IRI) in vitro [1], and in the systemic venous plasma of the conscious monkey [3] and the serum of man [7]. Because of the possibility that epinephrine-induced changes in hepatic insulin degradation might influence systemic, venous IRI concentrations, the examination of IRI concentration changes in the portal vein was undertaken. By sampling from the portal vein the effect of $1 \mu \mathrm{g} / \mathrm{kg} . \mathrm{min}$ of epinephrine ${ }^{1}$ on insulin release from the pancreas could be more accurately inferred from changes in plasma concentrations. Because of the implications of epinephrine as a physiological controller of insulin release, we wondered whether its infusion would result in a lessened increase in IRI in spite of a glucose rise, a continuation at baseline levels, or an actual decrease in portal plasma concentrations.

Ergotamine tartrate has been shown to block epinephrine's inhibitory action upon insulin release in vitro [1], and "dihydroergotamine opposes epinephrine's

* This research was supported in part by Grants: NASA NS-G-(T)-89, USPHS 6678-2, USPHS AM 09748-02

1 One indication that this dose may be physiological is MALMEJAd's report that hypotension causes the release of $0.997 \mu \mathrm{g} / \mathrm{kg} . \mathrm{min}$ from a single canine adrenal [5]. injurious effects on islet tissue" in the anesthetized dog [4]. We examined its effect on epinephrine's action in the conscious monkey.

\section{Material and Methods}

Male Rhesus (Macaca mulatta) monkeys weighing approximately $5 \mathrm{~kg}$ each, were prepared with chronic indwelling right internal jugular and portal vein catheters (polyvinyl chloride I.D. 0.047 inches, from Superenant, Clinton, Mass.) at least ten days before the experiments. This was accomplished under thiopental sodium anaesthesia with aseptic technique. The portal vein catheter was placed in a branch of the superior mesenteric vein, and advanced until contact was made with the liver, it was then retracted $2 \mathrm{~cm}$ and sutured in place. The catheters were led under the skin and brought through it lateral to the umbilicus, a point the animals could not reach because of a horizontal plastic plate placed under their arms but above the exit point [9]. The catheters were kept open by programmed infusions of a few drops of saline, containing small amounts of heparin, totaling less than $20 \mathrm{ml}$ of solution each day (about 1000 units of heparin per day).

The monkeys were seated for the duration of the experimental periods in routinely cleaned, continuously lighted, ventilated and closed wooden booths to reduce 
their exposure to varying external stimuli [6]. They were fed Purina Chow biscuits, apples, and oranges, and were given water ad libitum. They were always fed during the afternoon, and fasted for at least $15 \mathrm{~h}$ prior to the beginning of an experiment.

All experiments were performed between $8: 45$ and 10:15 a.m. in the following way: A control sample was collected from 0847 to 0850 in the same manner as all the samples by allowing blood to drip from the portal catheter, which was held $140 \mathrm{~cm}$ below the animal's umbilicus. The first of two infusions into the right jugular vein was then begun at a rate of $1 \mathrm{ml}$ per minute. It contained either saline $(0.85 \mathrm{~g}$ per cent) or ergotamine tartrate ${ }^{2}(14 \mu \mathrm{g} / \mathrm{kg} . \mathrm{ml})$ in saline. The second blood sample was obtained during the last three minutes of this ten-minute-long infusion. The second infusion was then begun immediately at the same rate of flow as the first, but containing either saline, epine-

2 Ergotamine tartrate U.S.P. Mann Research Laboratories, New York, N.Y.

Table 1. Levels of Plasma Insulin (mug per ml) and Plasma Sugar ${ }^{\mathrm{a}}$ (mg\%) in Portal Vein

\begin{tabular}{|c|c|c|c|c|c|c|}
\hline $\begin{array}{l}\text { Sample number } \\
\text { Time (mins) }\end{array}$ & $\begin{array}{r}1 \\
-10\end{array}$ & $\begin{array}{l}2 \\
0\end{array}$ & $\begin{array}{l}3 \\
8 \\
\end{array}$ & $\begin{array}{r}4 \\
15 \\
\end{array}$ & $\begin{array}{r}5 \\
25\end{array}$ & $\begin{array}{r}6 \\
60\end{array}$ \\
\hline $\begin{array}{l}\text { Monkey } \\
\text { Number }\end{array}$ & & $\begin{array}{l}\text { Saline } \\
-10 \text { to } 0\end{array}$ & $\begin{array}{l}\text { Epinephrine } \\
0 \text { to } 15\end{array}$ & & & \\
\hline 103 & $\begin{array}{r}4.7 \\
(71)\end{array}$ & $\begin{array}{r}8.3 \\
(69)\end{array}$ & $\begin{array}{l}1.9 \\
(98)\end{array}$ & $\begin{array}{c}1.7 \\
(131)\end{array}$ & $\begin{array}{c}9.8 \\
(163)\end{array}$ & $\begin{array}{l}4.2 \\
(71)\end{array}$ \\
\hline 103 & $\begin{array}{r}2.7 \\
(71)\end{array}$ & $\begin{array}{r}2.3 \\
(71)\end{array}$ & $\begin{array}{l}2.0 \\
(99)\end{array}$ & $\begin{array}{c}1.6 \\
(139)\end{array}$ & $\begin{array}{l}13.3 \\
(167)\end{array}$ & $\begin{array}{l}3.9 \\
(68)\end{array}$ \\
\hline 103 & $\begin{array}{r}9.5 \\
(75)\end{array}$ & $\begin{array}{r}1.8 \\
(70)\end{array}$ & $\begin{array}{l}2.0 \\
(89)\end{array}$ & $\begin{array}{c}1.7 \\
(139)\end{array}$ & $\begin{array}{l}22.5 \\
(167)\end{array}$ & $\begin{array}{l}3.9 \\
(69)\end{array}$ \\
\hline 132 & $\begin{array}{r}5.2 \\
(70)\end{array}$ & $\begin{array}{r}3.7 \\
(74)\end{array}$ & $\begin{array}{l}1.3 \\
(97)\end{array}$ & $\begin{array}{l}16.8 \\
(137)\end{array}$ & $\begin{array}{l}15.0 \\
(146)\end{array}$ & $\begin{array}{l}2.2 \\
(58)\end{array}$ \\
\hline 132 & $\begin{array}{r}1.6 \\
(71)\end{array}$ & $\begin{array}{r}1.6 \\
(63)\end{array}$ & $\begin{array}{l}1.2 \\
(88)\end{array}$ & $\begin{array}{c}1.0 \\
(137)\end{array}$ & $\begin{array}{l}20.7 \\
(167)\end{array}$ & $\begin{array}{l}1.9 \\
(63)\end{array}$ \\
\hline 138 & $\begin{array}{r}8.1 \\
(67)\end{array}$ & $\begin{array}{r}9.1 \\
(68)\end{array}$ & $\begin{array}{l}5.5 \\
(87)\end{array}$ & $\begin{array}{c}6.7 \\
(141)\end{array}$ & $\begin{array}{l}25.4 \\
(165)\end{array}$ & $\begin{array}{l}8.1 \\
(80)\end{array}$ \\
\hline 138 & $\begin{array}{l}19.5 \\
(86)\end{array}$ & $\begin{array}{l}22.2 \\
(88)\end{array}$ & $\begin{array}{l}6.4 \\
(93)\end{array}$ & $\begin{array}{l}10.7 \\
(129)\end{array}$ & $\begin{array}{l}35.3 \\
(183)\end{array}$ & $\begin{array}{l}4.2 \\
(68)\end{array}$ \\
\hline Mean $\pm \mathrm{SEM}$ & $\begin{array}{c}7.3 \pm 2.4 \\
(73 \pm 2)\end{array}$ & $\begin{array}{c}7.0 \pm 2.8 \\
(72 \pm 3)\end{array}$ & $\begin{array}{l}2.9 \pm 1.0 \\
(93 \pm 2) \\
\end{array}$ & $\begin{array}{c}5.7 \pm 2.3 \\
(136 \pm 2) \\
\end{array}$ & $\begin{array}{l}20.3 \pm 4.2 \\
(165 \pm 4)\end{array}$ & $\begin{array}{l}4.1 \pm 0.8 \\
(68 \pm 3)\end{array}$ \\
\hline \multirow[t]{2}{*}{$\begin{array}{l}\text { (No. } 1 \text { vs . . ) } \\
\text { cP. IRI }<-- \\
P \text {. Sugar }<--\end{array}$} & & $\begin{array}{l}0.9 \\
0.5\end{array}$ & $\begin{array}{l}0.05 \\
0.001 \\
\end{array}$ & $\begin{array}{l}0.6 \\
0.001 \\
\end{array}$ & \multirow[t]{2}{*}{$\begin{array}{l}0.001 \\
0.001\end{array}$} & \multirow[t]{2}{*}{$\begin{array}{l}0.2 \\
0.3\end{array}$} \\
\hline & & $\begin{aligned} & \text { Ergotamine } \\
&- 10 \text { to } 0 \\
&\end{aligned}$ & $\begin{array}{l}\text { Ergotamine } \\
0 \text { to } 15\end{array}$ & + Epinephrine & & \\
\hline$\overline{103}$ & $\begin{array}{r}1.5 \\
(71)\end{array}$ & $\begin{array}{r}3.6 \\
(73)\end{array}$ & $\begin{array}{r}6.5 \\
(92)\end{array}$ & $\begin{array}{l}15.2 \\
(112)\end{array}$ & $\begin{array}{l}12.9 \\
(127)\end{array}$ & $\begin{array}{c}5.9 \\
(133)\end{array}$ \\
\hline 138 & $\begin{array}{l}12.5 \\
(83)\end{array}$ & $\begin{array}{l}20.2 \\
(129)\end{array}$ & $\begin{array}{l}18.1 \\
(126)\end{array}$ & $\begin{array}{l}17.5 \\
(151)\end{array}$ & $\begin{array}{l}27.5 \\
(158)\end{array}$ & $\begin{array}{l}11.9 \\
(137)\end{array}$ \\
\hline 138 & $\begin{array}{r}5.1 \\
(68)\end{array}$ & $\begin{array}{l}15.1 \\
(83)\end{array}$ & $\begin{array}{l}11.7 \\
(115)\end{array}$ & $\begin{array}{l}12.8 \\
(146)\end{array}$ & $\begin{array}{l}16.7 \\
(134)\end{array}$ & $\begin{array}{c}9.2 \\
(118)\end{array}$ \\
\hline Mean \pm SEM & $\begin{array}{c}6.4 \pm 3.2 \\
(74 \pm 5) \\
\end{array}$ & $\begin{array}{l}13.0 \pm 4.9 \\
(95 \pm 17)\end{array}$ & $\begin{array}{l}12.1 \pm 3.2 \\
(111 \pm 10) \\
\end{array}$ & $\begin{array}{l}15.2 \pm 1.4 \\
(136 \pm 12) \\
\end{array}$ & $\begin{array}{l}19.0 \pm 4.4 \\
(140 \pm 9)\end{array}$ & $\begin{array}{r}9.0 \pm 1.7 \\
(129 \pm 6) \\
\end{array}$ \\
\hline \multirow[t]{2}{*}{$\begin{array}{l}(\text { No. } 1 \text { vs ...) } \\
P . \text { IRI }<-- \\
P . \text { Sugar }<--\end{array}$} & & $\begin{array}{l}0.2 \\
0.25\end{array}$ & $\begin{array}{l}0.01 \\
0.05 \\
\end{array}$ & $\begin{array}{l}0.1 \\
0.05 \\
\end{array}$ & \multirow[t]{2}{*}{$\begin{array}{l}0.01 \\
0.01\end{array}$} & \multirow[t]{2}{*}{$\begin{array}{l}0.25 \\
0.005\end{array}$} \\
\hline & & $\begin{aligned} & \text { Saline } \\
&-10 \text { to } 0 \\
&\end{aligned}$ & $\begin{array}{l}\text { Saline } \\
0 \text { to } 15\end{array}$ & & & \\
\hline 103 & $\begin{array}{l}4.1 \\
(68)\end{array}$ & $\begin{array}{l}3.8 \\
(67)\end{array}$ & $\begin{array}{r}3.4 \\
(77)\end{array}$ & $\begin{array}{l}2.6 \\
(71)\end{array}$ & $\begin{array}{r}2.3 \\
(69)\end{array}$ & $\begin{array}{l}4.5 \\
(72)\end{array}$ \\
\hline 138 & $\begin{array}{l}7.7 \\
(70)\end{array}$ & $\begin{array}{l}9.4 \\
(75)\end{array}$ & $\begin{array}{l}11.0 \\
\langle 68\rangle\end{array}$ & $\overline{(65)}$ & $\begin{array}{l}11.3 \\
(70)\end{array}$ & $\begin{array}{l}6.2 \\
(73)\end{array}$ \\
\hline Mean $\pm \mathrm{SEM}$ & $\begin{array}{l}5.9 \pm 1.8 \\
(69 \pm 1)\end{array}$ & $\begin{array}{l}6.6 \pm 2.8 \\
(71 \pm 6)\end{array}$ & $\begin{array}{l}7.2 \pm 3.8 \\
(72 \pm 4)\end{array}$ & $\overline{(68} \pm 3)$ & $\begin{array}{l}6.8 \pm 4.5 \\
(70 \pm 1)\end{array}$ & $\begin{array}{l}5.3 \pm 0.9 \\
(73 \pm 1)\end{array}$ \\
\hline
\end{tabular}

a Plasma sugar in parentheses

b Time represents termination of 3 -minute drawing period

c All $P$ values paired t test 
phrine bitartrate ${ }^{3}$ ( $\left.1 \mu g / k g . m l\right)$, or epinephrine and ergotamine tartrate. The third blood sample was procured from the fifth to the eighth minute of this infusion; the fourth sample from the twelfth to the fifteenth. The second infusion was stopped and the fifth and sixth (final) samples were collected between the seventh to tenth and $42 \mathrm{nd}$ to 45 th minute after the termination of the infusion. All blood samples were collected in tubes containing approximately 50 units of heparin, the final concentration being less than $20 \mathrm{U}$ per $\mathrm{ml}$ blood. They were centrifuged promptly and the plasma was separated and frozen $\left(-20^{\circ} \mathrm{C}\right)$ until analyzed for insulin and reducing sugars.

Immunoreactive insulin (IRI) was assayed with the double antibody technique [8] using monkey insulin standards, kindly supplied by Mrs. Frances Wherry of the Walter Reed Army Institute of Research. The standard curve was developed from known weights of a mixture of Rhesus and Cynomolgus monkey insulin.

It was found that epinephrine bitartrate added to monkey plasma to produce concentrations of 0.004 , 0.4 , and $4.0 \mu \mathrm{g}$ per $\mathrm{ml}$ did not affect the determination of IRI concentrations.

Plasma concentrations of reducing sugars were determined with a Technicon Auto-Analyzer using the ferricyanide reduction method [2].

Seven infusions of saline followed by epinephrine, three of ergotamine followed by ergotamine plus epinephrine, and two of saline followed by saline infusions were performed.

\section{Results}

The results of the three types of double infusions are shown in Table 1.

During the saline-epinephrine infusions, portal vein IRI concentrations decreased during the epinephrine portion of the infusion, and rose dramatically at its termination. The mean of the first sample (No. 1) was compared with the mean of the other five samples (No. 2-6) by the $T$ test for paired samples ${ }^{4}$. The decreased mean insulin concentration in the third sample was associated with an increase in sugar concentration.

During the first part of the ergotamine- ergotamine plus epinephrine infusions, ergotamine alone caused an insignificant rise in IRI concentration. When ergotamine plus epinephrine were infused, the mean IRI remained above its control value. Mean insulin rose significantly, whereas with epinephrine alone it decreased. This suggests that ergotamine blocked the epinephrine inhibition of insulin release. Mean sugar

3 Epinephrine bitartrate U.S.P. Amend Drug \& Chemical Co., New York. This was mixed with saline within $10 \mathrm{~min}$ of the start of its infusion.

${ }^{4} t=\bar{x} / s / \sqrt{n}$ where $\bar{x}$ is the mean of the differences between the paired observations, $s$ is the standard deviation of the differences and $\mathbf{n}$ the number of paired samples [10]. concentration increased during this type of infusion suggesting that there was no effect of the ergotamine on the glycogenolytic effect of epinephrine. In addition, comparison of the IRI, blood sugar relationship suggests that the rising sugar probably was responsible for the rise in IRI.

\section{Discussion}

Infusion of epinephrine bitartrate in high, but pos. sibly physiological, quantities 1 is associated with a significant decrease in mean IRI concentrations in portal vein plasma. This occurs concomitantly with a significant rise in plasma sugar levels. The addition of ergotamine tartrate to the epinephrine infusion prevents a fall in IRI concentrations.

These results confirm the findings of Coore and RANDLE [1], who using segments of rabbit pancreas in vitro demonstrated that epinephrine bitartrate inhibited a glucose-stimulated insulin release, and that ergotamine tartrate blocked the epinephrine effect. The findings extend the preliminary results of KRIs et al., who demonstrated, in two experiments in which sampling was done from the portal vein of the conscious monkey, that large epinephrine infusions $(44 \mu \mathrm{g} / \mathrm{kg}$. min) decreased insulin concentrations to below detectable levels by the method used [3]. It is evident from the present data in which smaller amounts of epinephrine ( $1 \mu \mathrm{g} / \mathrm{kg} . \mathrm{min}$ ) were employed, that portal vein insulin concentrations do not drop to near zero but rather decrease to approximately $40 \%$ of initial levels.

PorTw has demonstrated that phentolamine, an alpha-adrenergic blocking agent, prevents the effect of epinephrine on peripheral vein IRI concentrations in man [7]. The ergotamine infusions, which block both alpha and beta-adrenergic receptors, also appear to prevent the IRI decrease engendered by epinephrine [7]. It is of interest that the mean plasma sugar is identical in sample number 4 in both the epinephrine and in the epinephrine plus ergotamine experiments. However, almost three times the concentration of plasma insulin is seen during the latter, suggesting that the rise in plasma glucose is stimulating insulin secretion.

It is unclear whether elevated IRI concentrations of the ergotamine infusions (number two samples) are in part due to alpha-adrenergic blockade of endogenous epinephrine's effect on the pancreas, or whether the insulin rise is secondary to the sugar increase. The latter is probably the case, as one would expect lower, not higher, plasma sugar concentrations if the IRI rise was the primary event. This conclusion is supported by the fact that PoRTw found no rise in peripheral sugar or IRI during an hour-long infusion of phentolamine in a single patient [7]. One explanation of the elevated sugar concentrations of the number two samples and the still elevated sugar and IRI values of the sixth samples is a general sympathetic nervous system activation. Both animals appeared pale during the 
ergotamine infusions, and monkey 103 retched shortly after one experiment.

Taken as a whole, these results suggest that epinephrine does play a physiological role in the regulation of insulin release in primates.

Acknowledgements. The authors wish to thank Drs. JAMnES L. WHITTENBERGER and JANE WOROESTER for helpful criticism, and Mr. Wirtiam KeITh, Mrs. Anna Karass and Mrs. Marta Gringergs for valuable technical aid.

\section{References}

1. Coone, H.G., and P.J. RANDLE: Regulation of insulin secretion studied with pieces of rabbit pancreas incubated in vitro. Biochem. J. 93, 66-78 (1964).

2. HoFrmaN, W.S.: A rapid photoelectric method for the determination of glucose in blood and urine. J. biol. Chem. 120, 51-55 (1937).

3. KrIS, A.O., R.E. MILdAr, F.E. WHERRY, and J.W. Masor: Inhibition of insulin secretion by infused epinephrine in Rhesus monkeys. Endocrinology 78, $87-97$ (1966).

4. Loubatimreis, A., M.M. Martant, J. Chapal, J. Taylor, M. H. Houareat, et A. M. Rondot: Action nocive de l'adrénaline pour la structure histologique des ilots de Langerhans du pancréas. Action protectrice de la dihydroergotamine. Diabetologia 1, 13-20 (1965).
5. Matmindad, J.: Activity of the adrenal medulla and its regulation. Physiol. Rev. 44, 186-218 (1964).

6. Mason, J.W.: Psychological influences on the pituit ary-adrenal cortex system. Recent Progr. Hormone Res. 15, 345-389 (1959).

7. Porte, D., Jr.: A receptor mechanism for the inhibition of insulin release by epinephrine in man. J. clin. Invest. 46, 86-94 (1967)

8. SOELDNER, J.S., and D. StoNE: Critical variables in the radioimmunoassay of serum insulin using the double antibody technic. Diabetes 14, 771-779 (1965).

9. Werdegar, D., D.G. Johnson, and J.W. Mason: A technique for continuous measurement of arterial blood pressure in anesthetized monkeys. J. appl. Physiol. 19, 519-521 (1964).

10. Worcester, J.: The statistical method. New Engl. J. Med. 274, 27-36 (1966)

R.E. MILt.ER, B.A., M.D., M.S.

Harvard School of Public Health Boston, Massachusetts

J.S. SoELDNER, B.Sc., M.D.

Associate in Medicine,

Peter Bent Brigham Hospital

Associate in Medicine, Harvard Medical School

Research Associate, Elliott P. Joslin

Research Laboratory

Boston, Massachusetts 